\title{
Physalis philadelphica Lam. (Solanaceae), a new alien species in the flora of Bosnia and Herzegovina
}

\author{
Semir Maslo ${ }^{1} \&$ Šemso Šarić \\ ${ }^{1}$ Primary School, Lundåkerskolan, Gislaved, Sweden; semmas@edu.gislaved.se \\ 2 Jelaške, Olovo, Bosnia and Herzegovina; semsosumar@gmail.com
}

Maslo S. \& Šarić Š. (2021): Physalis philadelphica Lam. (Solanaceae), a new alien species in the flora of Bosnia and Herzegovina. - Thaiszia - J. Bot. 31 (1): 081-086.

\begin{abstract}
Physalis philadelphica Lam. native to Mexico is now widely grown for its edible fruits ('tomatillo'). It has been recorded as a new alien species to the vascular flora of Bosnia and Herzegovina. In Bosnia and Herzegovina, P. philadelphica is reported from only one locality near the town of Zavidovići in Central Bosnia in September 2020. The specimens were growing along the banks of the Krivaja River in the vicinity of the village Ribnica. Brief information on the species distribution in Bosnia and Herzegovina and a short morphological description are given, as well as a key to Physalis species occurring in the Balkans.
\end{abstract}

Keywords: casual alien, distribution, morphology, new record, tomatillo.

\section{Introduction}

The genus Physalis L. (Solanaceae) is a genus of approximately 90 species, which are mostly American (Mexico, USA and Central America, reaching South America) except the Eurasian P. alkekengi L. (Arenas \& Kamienkowski 2013). P. alkekengi L. was recently placed in the monotypic genus Alkekengi Miller. typified with $A$. officinarum Moench. (Applequist 2012). Within the genus Physalis, only 11 species have been recorded in Europe of which seven have been reported in the Balkans: $P$. alkekengi L., P. angulata L., P. heterophylla Nees, P. ixocarpa Hornem., P. peruviana L., P. philadelphica Lam. and P. pubescens L. (Valdés 2012). Up to now P. alkekengi 
was the only species of the genus reported in Bosnia and Herzegovina (BeckMannagetta et al. 1967).

P. philadelphica has the status of casual species in Austria (Polatschek et al. 2001), Belgium (D'hose \& De Langhe 1977; Verloove \& Vandenberghe 1996), Czech Republic (Danihelka et al. 2012), Denmark (Axelius 1991), Great Britain (Clement 1979; Grenfell 1983), Greece (Dimopoulos et al. 2013) and Sweden (Axelius 1991); and of naturalized species in Portugal (Fernandes 1970) and Spain (Carretero 1983; Del Monte \& Sobrino 1993). Recently it was found in Bulgaria (Vladimirov \& Tashev 2017) and Italy (Fanfarillo 2019).

The aim of the article is to report the first record of the species in the flora of former Yugoslavia, especially in Bosnia and Herzegovina.

\section{Material and Methods}

The field study was conducted at the beginning of September 2020. Digital photographs and GPS coordinates were taken in the field by an iPhone GPS app. The identification of the specimens was done according to Sell \& Murrell (2009) and Verloove (2020). The nomenclature follows the Euro-Med checklist (EURO+MED 2006). The voucher specimen from the locality near the Ribnica, Zavidovići is deposited in the Herbarium of the National Museum of Bosnia and Herzegovina (SARA).

\section{Results and Discussion}

$P$. philadelphica is an annual, $40-60 \mathrm{~cm}$ high. Stems are pale green, erect, branched, leafy with a few hairs. Leaves are alternate or sometimes geminate, ovate to ovatelanceolate, the lamina $2-10 \times 1-4 \mathrm{~cm}$, acuminate, cuneate at the base, entire or sinuate to somewhat dentate toward the base, dark green on upper surface, somewhat paler beneath, with a few, scattered hairs; petiole (1)2-5 cm. Inflorescence of solitary, axillary, bisexual flowers, pedicles $5-10 \mathrm{~mm}$ long. Calyx 4$10 \mathrm{~mm}$, green and often purple-veined, accrescent and $30-50 \mathrm{~mm}$ in fruit, campanulate, divided up to halfway to the base into 5 lobes, the lobes ovate with a few hairs. Corolla 5-30 mm in diameter, yellow, with brownish-purple marking at the throat, subentire. Stamens 5, exserted; filaments purple, anthers twisted after anthesis. Style 1; stigma capitates. Berry 13-40(-60) mm, green to purple, filling and sometimes splitting calyx; seeds suborbicular. Chromosome counts are $2 n=24$ (mainly adapted from Sell \& Murrell 2009).

To identify this new alien species, we present an adjusted key to the species of Physalis in the Balkans, based on Sullivan (2004), Bean (2006) and Verloove (2020).

1a Corolla white or cream, rotate. Fruiting calyx orange or red at maturity. Rhizomatous perennial P. alkekengi

1b Corolla yellowish, often with purplish or brownish spots at throat, campanulate. Fruiting calyx green at maturity. Annual or perennial 2 
2a Stem densely pubescent (villous to sericeous), hairs multicellular. Corolla always with dark spots at throat

$2 \mathrm{~b}$ Stem subglabrous (younger parts often with scattered, simple hairs). Corolla with or without dark spots at throat

3a Corolla 9-15 mm in diameter. Anthers 1-3 mm long. Fruiting calyx 15-30 mm wide. Leaves truncate, often oblique at base, acute at apex, usually entire or unevenly toothed; annual

P. pubescens

3b Corolla 15-25 mm in diameter. Anthers 3-5 mm long; perennial

4

4a Anthers 3-4 mm long, deep blue-purple, filaments slender. Fruiting calyx 30-50 mm wide, peduncle $20-30 \mathrm{~mm}$ long. Hairs not viscid P. peruviana

4b Anthers 2.5-4.5 mm long, yellow, sometimes tinged with blue, filaments as wide as the anthers, often clavate. Fruiting calyx 20-30 mm wide, peduncle $20-30 \mathrm{~mm}$ long. Hairs viscid

P. heterophylla

5a Throat of corolla unspotted or with faint dark spots. Fruiting calyx angular. Peduncle 5-10 $\mathrm{mm}$ in anthesis, much elongating in fruiting (up to $40 \mathrm{~mm}$ long) P. angulata

$5 b$ Throat of corolla with distinct dark spots. Fruiting calyx terete. Peduncle up to $5 \mathrm{~mm}$ in anthesis, slightly elongating at fruiting (up to $15 \mathrm{~mm}$ long) .... 6

$6 a$ Anthers ca $2 \mathrm{~mm}$ long, not twisted after anthesis. Corolla 5-10 mm in diameter .P. ixocarpa $6 \mathrm{~b}$ Anthers 3-5 mm long, twisted after anthesis. Corolla 10-30 mm in diameter P. philadelphica

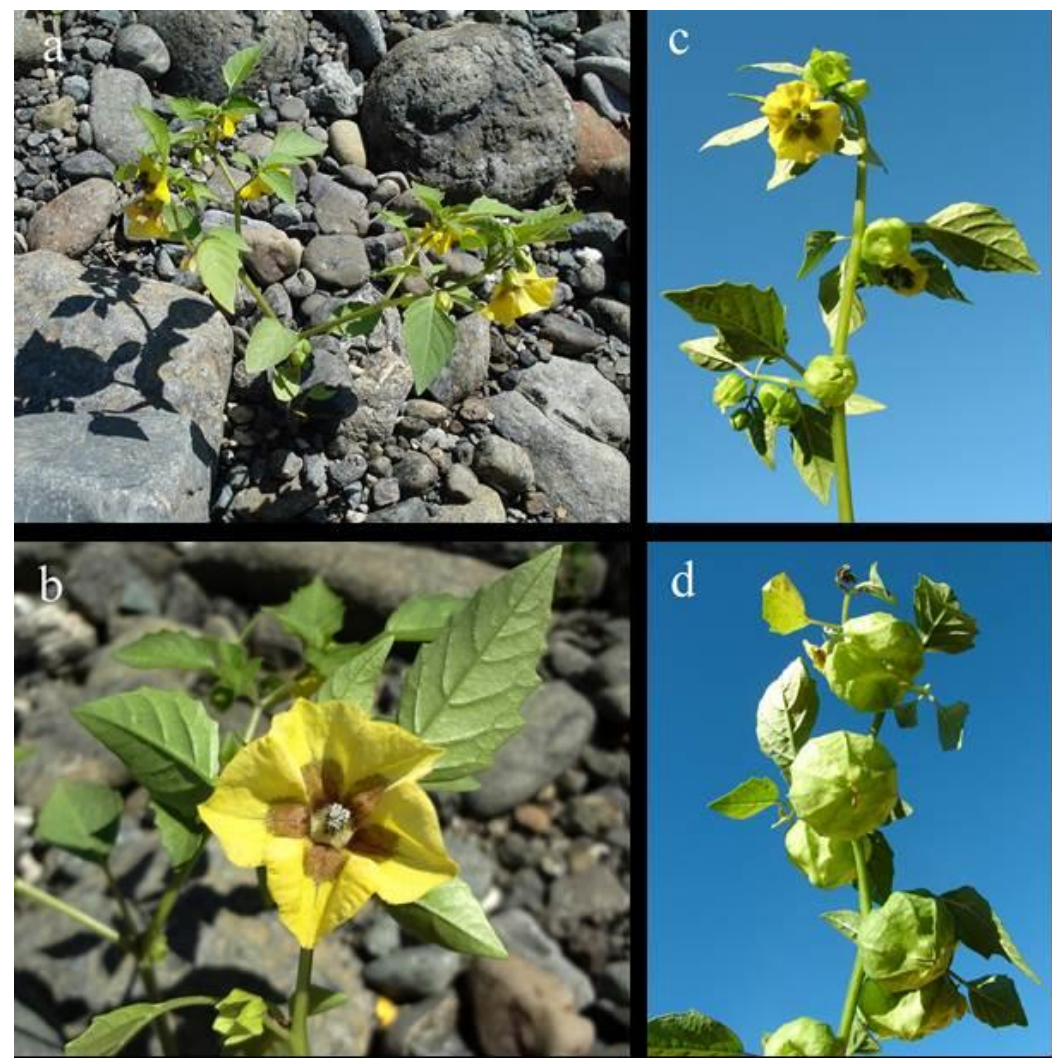

Fig. 1 Physalis philadelphica Lam. on gravel bars along the banks of the Krivaja River: a - habitat bflower $\mathrm{c}$ - part of inflorescence $d$-young fruits (Photos by authors). 
During fieldwork in the beginning of September 2020, P. philadelphica was found in one locality around the town of Zavidovići (Central Bosnia) (Fig. 2). Only two flowering plants with young fruits were observed on the gravelly and sandy banks of the river Krivaja in the vicinity of the village Ribnica near Zavidovići (44²1'10.18" N; 18²3'35.36" E; elevation 307 m.) (Fig. 1a). In this locality, P. philadelphica was accompanied by Amaranthus blitum L., A. hybridus L., A. retroflexus L., Echinochloa crus-galli (L.) P. Beauv., Helianthus annuus L., Ipomoea purpurea (L.) Roth., Lycopersicon esculentum Mill., Panicum dichotomiflorum Michx., Solanum dulcamara L. and Sorghum halepense (L.) Pers.

$P$. philadelphica is considered mostly as casual alien species in Europe (Valdés 2012). On the other hand, this species has been introduced for cultivation for the edible berries in some Mediterranean countries. Due to former cultivation the species is reported to be locally established alien species in Portugal and Spain (Del Monte \& Sobrino 1993).

In Bosnia and Herzegovina, this species is currently a casual species, and it is unlikely that it will establish and reproduce the population itself in the next year (the inflated calyces on the Bosnian plants were empty, with no developed fruits). This annual plant is easy to grow, but two or more plants are needed to set fruit because individual plants are not self-compatible. The exact origin of the plants from Bosnia remains uncertain, but most likely a fruit or some seeds obtained from kitchen waste were thrown in this locality. The potential invasive behaviour of the species should be monitored in the following years. It is important to note that another naturalized culinary species, namely Salvia hispanica L., has recently been recorded in the nearby village (Maslo \& Šarić 2020). Like the $P$. philadelphica, it reached nature probably through kitchen waste. The villages could be the source of new viable seeds, and that indicates that more plants of both species will appear in similar habitats in the future.

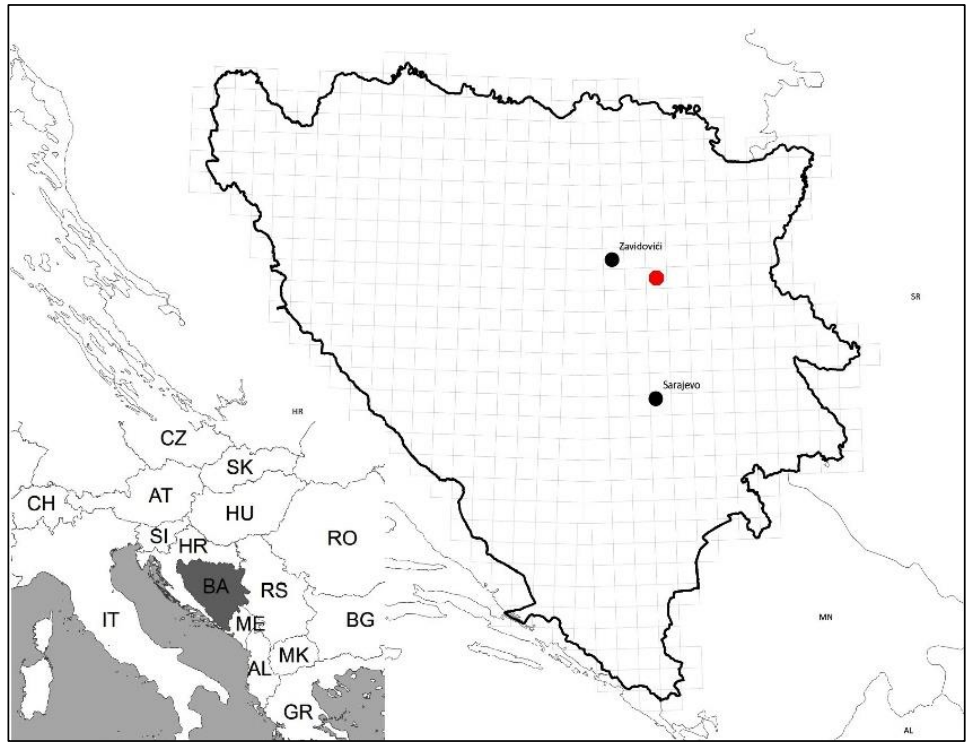

Fig. 2 The recent findings of Physalis philadelphica Lam. in Bosnia and Herzegovina (new record is indicated by red). 


\section{Acknowledgement}

We would like to thank Aldin Boškailo (Mostar, Bosnia and Herzegovina) for mapping the distribution of the species and Lanna Maslo (Malmö, Sweden) for improving the English of this paper.

\section{References}

Applequist W. L. (2012): Report of the nomenclature committee for vascular plants: 64. Taxon 61(5): 1112-1113. DOI: 10.1002/tax.615019

Arenas P. \& Kamienkowski N. M. (2013): Ethnobotany of the genus Physalis (Solanaceae) in the South American Gran Chaco. - Candollea 68(2): 251-266. doi.org/10.15553/c2012v682a9

Axelius B. (1991): Cultivated species of Physalis. - Sven. Bot. Tidskr. 85: 413-416.

Beck-Mannagetta G., Maly K. \& Bjelčić Ž. (eds) (1967): Flora Bosnae et Hercegovinae 4, Sympetalae 2: Zemaljski muzej Bosne i Hercegovine u Sarajevu, Sarajevo 1-112 pp.

Bean A. R. (2006): Physalis (Solanaceae) in Australia - nomenclature and identification. Austr. Syst. Bot. Soc. Newslett. 127: 6-9.

Carretero J. L. (1983): Chenopodium pumilio R.Br. y Physalis philadelphica Lam. en España. Collectanea botanica a Barcinonensi Botanico Instituto edita 14: 211-213.

Clement E. J. (1979): Aliens and adventives. Adventive news 13. Mixed bag. - BSBI News 21 14-19.

Danihelka J., Chrtek J. \& Kaplan Z. (2012). Checklist of vascular plants of the Czech Republic. - Preslia 84: 647-811.

Del Monte J. P. \& Sobrino E. (1993): Solanum sarrachoides and Physalis philadelphica (Solanaceae) in Spain - two largely neglected weeds. - Willdenowia 23: 91-96.

Dimopoulos P., Raus T., Bergmeier E., Constantinidis T., latrou G., Kokkini S., Strid A., \& Tzanoudakis D. (2013): Vascular plants of Greece. An annotated checklist. - Botanic gardens and botanical museum Berlin-Dahlem, Berlin and Hellenic botanical society, Athens. 372 pp.

D’hose R. \& De Langhe J.-E. (1977): Nieuwe groeiplaatsen van zeldzame planten in België. V. - Bull. Koninkl. Belg. Bot. Ver. 110: 20-28.

Euro+Med 2006+ (continuously updated): Euro+Med PlantBase - the information resource for Euro-Mediterranean plant diversi-ty. - http://ww2.bgbm.org/EuroPlusMed (accessed September 2020).

Fanfarillo E. (2019): Physalis philadelphica Lam. (Solanaceae). - In: Galasso G. et al.: Notulae to the Italian alien vascular flora: 7. - Ital. Bot. 7: 157-182. doi: 10.3897/italianbotanist.7.36386

Fernandes R. B. (1970): Sur l'identification d'une espèce de Physalis souspontanée au Portugal. - Bol. Soc. Brot. 44: 343-367.

Grenfell A. L. (1983): Aliens and adventives. Adventive News 26. More on Solanaceae in Britain. - BSBI News 35: 12-14.

Maslo S. \& Šarić Š. (2020): Salvia hispanica L. Lamiaceae, a new alien species in the flora of Bosnia and Herzegovina and the Balkans. - Thaiszia - J. Bot. 30(1): 31-36. doi.org/10.33542/TJB2020-1-03

Polatschek A., Maier M. \& Neuner W. (2001): Samenpflanzen: Rubiaceae bis Vitaceae; Einkeimblättrigen: Alismataceae bis Orchidaceae - Flora von Nordtirol, Osttirol und Vorarlberg 4: 1-1083 pp. 
Sell P. \& Murrell G. (2009): Flora of Great Britain and Ireland. Vol. 3 Mimosaceae Lentibulariaceae. - Cambridge University Press, Cambridge: XXVIII + 595 p.

Sullivan J. R. (2004): The genus Physalis (Solanaceae) in the southeastern United States. Rhodora 106: 305-326.

Valdés B. (2012): Solanaceae. - In: Euro+Med PlantBase - the information resource for EuroMediterranean plant diversity (accessed September 2020).

Verloove F. \& Vandenberghe C. (1996): Nieuwe en interessante voederadventieven voor de Belgische flora, hoofdzakelijk in 1995. - Dumortiera 66: 11-32.

Verloove F. (2020): Physalis L. - In: Manual of the alien plants of Belgium, Botanic Garden of Meise, Belgium; at: alienplantsbelgium.be (accessed September 2020).

Vladimirov V. \& Tashev A. (2017): Reports 139-144. - In: Vladimirov V., Aybeke M., Matevski V. \&Tan K. (eds.): New floristic records in the Balkans 34. - Phytol. Balcan. 23(3): 413-444.

Received: October $6^{\text {th }} 2020$

Revised: December $1^{\text {st }} 2020$

Accepted: December $15^{\text {th }} 2020$ 